\title{
"Batizando e ressignificando práticas pedagógicas" " no ensino da língua materna: o papel da formação continuada
} "Baptizing and reframing pedagogical practices" in mother tongue education: the role of continuing education

Adriane Angheben Eitelven*

E. M. E. F. Dr. Tancredo de Almeida Neves

Bento Gonçalves - Rio Grande do Sul / Brasil

Cátia de Azevedo Fronza**

Universidade do Vale dos Sinos - UNISINOS

São Leopoldo - Rio Grande do Sul / Brasil

RESUMO: Neste trabalho, reflete-se sobre questionamentos de professores que participaram de um programa de formação continuada ocorrido no Rio Grande do Sul, oferecido pelo Ministério da Educação, em parceria com a Secretaria Municipal de Educação. Parte-se das impressões que os educadores tinham no início da referida formação, comparando-as às compreensōes explicitadas ao final do curso. Neste período de formação, compartilhando experiências e conhecimento, aliando teoria e prática, dúvidas e inquietações foram dando espaço a novas perspectivas para reavaliar e modificar o fazer pedagógico. Destaca-se que o letramento, assumido em todo o processo de ensino e de aprendizagem, é, acima de tudo, ensinar o aluno a falar, ver, ouvir, ler, escrever, calcular, entre tantas outras habilidades. Todavia, primeiro, os professores precisam aprender a fazê-lo.

PALAVRAS-CHAVE: formação continuada, alfabetização, linguagem.

ABSTRACT: This paper reflect son questions of teachers who attended a continuing education program that occurred in Rio Grande do Sul, offered by the Ministry of Education, in partnership with the Municipal Department of Education. This article presents the impressions that educators had at the beginning

\footnotetext{
${ }^{1}$ Trecho entre aspas dito por uma professora durante a formação continuada. Esta fala é aqui apresentada, porque revela a intenção do trabalho desenvolvido.

* adrianea@italnet.com.br

**1cfronza@uol.com.br
} 
of the training so as to discurs and compare these impressions to the understandings expressed at the end of the course. In this period of training, sharing experiences and knowledge, allying theory and practice, questions and concerns were giving way to new perspectives to reevaluate and modify the teaching practice. It is important to say that literacy, seen as present in the whole teaching and learning processes, is, above all, to teach the student to speak, see, hear, read, write, calculate, among other skills. However, first, the teachers need to learn how to do it.

KEYWORDS: continuing education, literacy, language.

\section{Introdução}

Neste artigo, relatam-se momentos de um trabalho desenvolvido com dois grupos de professores de séries iniciais participantes do programa de formação continuada Pró-Letramento Alfabetização e Linguagem, oferecido pelo Ministério de Educação e Cultura - MEC - e coordenado pela Universidade Federal de Pernambuco, em parceria com o município de Bento Gonçalves RS, no período de setembro de 2008 a julho de 2009 . O objetivo central deste trabalho é analisar a construção de conhecimento desses profissionais da educação como busca de uma identidade profissional / individual e coletiva / de grupo. Em síntese, visa contribuir no sentido de confirmar que a forma mais efetiva de melhorar os índices de aprendizagem dos alunos do Ensino Fundamental encontra-se no estudo do professor, sujeito que atua diretamente com o processo ensino-aprendizagem. Nesse aspecto, torna-se imprescindível às instituições de pesquisa e aos órgãos responsáveis pela educação engendrarem açôes que ofereçam meios para que o docente dialogue, ao mesmo tempo, com a teoria e a prática pedagógica. De fato, as próprias educadoras revelaram que conversam muito sobre os problemas de aprendizagem, contudo sentem-se aflitas ao serem questionadas sobre quais são esses problemas e como resolvêlos. O estudo aponta para o fato de que, sem o aparato teórico, não há respostas para os questionamentos, uma vez que a metodologia aplicada é provida quase que unicamente do empirismo.

\section{Professor: um sujeito em busca de respostas}

Para compreender as afirmativas anteriores, é necessário descrever alguns momentos respectivos aos grupos de estudos mencionados. No primeiro dia do encontro de formação, a primeira tarefa sugerida às cursistas foi a elaboração de uma pergunta para a qual cada professora desejasse respostas sobre diferentes temas, como letramento, alfabetização, gênero discursivo, leitura, oralidade, produção 
de texto, avaliação. As temáticas com o maior índice de questionamentos foram produção de texto, leitura, alfabetização e letramento. Esse momento foi intenso no sentido de que as professoras debateram seus problemas em subgrupos, de acordo com a temática. Logo, percebeu-se que identificaram-se com as mesmas angústias. Individualmente, expuseram suas perguntas ao grande grupo, que procurava contribuir com sugestôes ao problema. Como não encontravam uma resposta clara, solidariamente, avaliavam o quanto de progresso o professor já havia alcançado com seu aluno, seja na escrita, seja na leitura, valorizando, dessa forma, o empenho e dedicação do educador. A primeira expectativa, diante dos questionamentos revelados, foi a de que talvez o programa fosse ao encontro dessas necessidades, uma vez que a metodologia da formação continuada é aliar teoria à prática de sala de aula. Muitas comentaram: "é por isso que estamos fazendo o pró-letramento, estamos em busca de respostas".

O grupo teve as primeiras incursões teóricas ao ser questionado sobre os conceitos de linguagem, alfabetização e letramento. Uma imagem de Joseph Russafa (novelo e tecido sendo tricotado), citado por Nery (2007), provocou algumas afirmativas sobre o primeiro tema citado. A maioria dos educadores contribuiu com ideias, entendendo linguagem como diálogo / escrita / diferentes textos /construção de conhecimento. Após, foi lida a história das irmãs Amala e $\mathrm{Kamala}^{2}$ (indianas criadas por lobos) e debatido o porquê de elas não conseguirem se adaptar à vida dos "humanos" e não terem sentimentos ou ações emotivas, já que eram duas crianças. Uma cursista concluiu que a falta da linguagem humana também impossibilitou o desenvolvimento do afeto entre as irmãs.

A partir disso, ocorreu o diálogo a respeito do papel da linguagem nas interações sociais, na construção da identidade individual e de grupo e de como a linguagem constrói uma cultura. Para Paviani (2004, p. 75), "o ser humano só adquire consciência de si ao se dar conta de sua criação cultural, ao compreender o seu estar no mundo com os outros e com as coisas", ou seja, a humanização se dá pelo processo cultural (história-linguagem), e o homem só se torna humano no viver humano. Por sua vez, a escola é a instituição de ensino criada, organizada e planejada com o objetivo de ministrar um ensino

\footnotetext{
${ }^{2}$ Amala e Kamala, também conhecidas como as meninas lobo, são duas crianças selvagens encontradas na Índia no ano de 1920. A primeira delas tinha um ano e meio e faleceu um ano mais tarde. Kamala, no entanto, já tinha oito anos de idade, e viveu até 1929. Origem: Wikipédia, a enciclopédia livre.
} 
coletivo. Qual o papel do professor, então? Ele está preparado para conduzir esse ensino coletivo e lidar com as diferentes aprendizagens / linguagens de um grupo de alunos? Em suma, o trabalho desenvolvido pela escola é permeado pelo contato com múltiplas linguagens, mas estas, muitas vezes, não são refletidas e interpretadas dentro de um contexto significativo e compreensível.

Mais uma vez, volta-se à questão da identidade do sujeito professor e do sujeito aluno: ambos estão em constante construção e reconstrução. Da mesma forma, quando o sujeito professor se modifica, a instituição escola também sofre o processo, uma vez que o movimento é dialético, e as mudanças ocorrem na comunidade em geral, pois a escola são os grupos que nela convivem: professores, alunos, funcionários, pais. Por meio dessas interações ocorre a modificação de uma cultura, já que educação não é somente conhecimento, mas envolve, além desse, crenças, hábitos, atitudes, costumes, habilidades.

Como se vê, trata-se de uma atividade simples, contudo rica, uma vez que refletiu a importância do professor como ser humano que interage e disponibiliza ao seu educando o contato com diferentes linguagens. Somandose a isso, o grupo inferiu a respeito do poder do conhecimento, promovendo um momento bastante profícuo, pois o estudo assumia excelência. Após a discussão, uma professora assim concluiu: "Somos a soma das interações que tivemos durante nossa vida".

\section{Professor: um sujeito aprendiz}

Com base nessa reflexão inicial, considerou-se relevante analisar a imagem da capa do livro de Magda Soares (2008) que traz como ilustração o tricotar da letra A (de alfabetização). Uma cursista levantou a hipótese de que as duas agulhas tricotando a letra "A" representam o trabalho do professor no processo de alfabetização e letramento. Logo, era necessário ter clareza desses conceitos. Então, fazendo uso dos escritos de Soares, explicou-se a origem e o significado de analfabetismo para compreender a alfabetização. O prefixo grego "a" indica "privação, falta de", e o sufixo "ismo" indica "modo de proceder, de pensar". Analfabeto é, portanto, a pessoa que não conhece o alfabeto. O conceito de alfabetizar é explicado pelo sufixo "izar", que indica "tornar, fazer com que", de maneira que alfabetizar consiste em tornar o individuo capaz de ler e de escrever. Alfabetização é a "ação de alfabetizar, de tornar alguém alfabeto" (SOARES, 2008, p. 28-29). Nesse momento, percebeu-se certa confusão nos olhares das cursistas, já que certamente se perguntavam em que parte disso se encaixaria o letramento. 
No material de estudos oferecido pelo Ministério da Educação consta o conceito de letramento:

Letramento é o resultado da ação de ensinar ou de aprender a ler e escrever, bem como o resultado da ação de usar essas habilidades em práticas sociais, é o estado ou condição que adquire um grupo social ou um indivíduo como consequência de ter-se apropriado da língua escrita e de ter-se inserido num mundo organizado diferentemente: a cultura escrita (Pró-letramento, 2008, p.11).

Para maior clareza dos conceitos de letramento e alfabetização, socializou-se o texto Alfabetização e letramento: caminhos e descaminhos (SOARES, 2004). Com base nesse texto, perguntou-se: o que a autora propóe ser o caminho e o descaminho? Após releitura e debate, chegou-se ao consenso de que o descaminho seria trabalhar somente a alfabetização ou o letramento, e o caminho seria o trabalho simultâneo. Nessa perspectiva, ficou clara a importância de o professor trabalhar a alfabetização para a criança ter o domínio do código escrito associado ao processo de letramento, visto que esse último dará sentido e motivação ao aluno, não privilegiando um sobre o outro, mas, sim, articulando-os. Uma professora comentou que leitura é "movimento". Outra relatou a experiência da mãe que foi alfabetizada na infância, mas afirmou que só agora lê e compreende o que está escrito. Juntos, constatamos que a mãe da colega foi alfabetizada, mas não letrada; o tempo e a experiência de vida transformaram-na numa pessoa capaz, mas, durante muitos anos, não usufruiu dessa capacidade. De fato, a escola é a maior "agência de letramento" (KLEIMAN, 1995, p. 20) e, portanto, ela não pode se preocupar somente com a alfabetização.

Nessa primeira etapa, o programa Pró-Letramento enfocou a alfabetização e o letramento numa perspectiva de processos distintos, que demandam distintas metodologias, mas paralelos na aplicação em sala de aula. A importância firmou-se na compreensão, por parte das cursistas, em reconhecer as especificidades da alfabetização e de que esta deve se realizar dentro de um contexto de letramento. Por conseguinte, os grupos de estudo tornaram-se cúmplices nessa tarefa, ao refletirem sobre o enfoque de aprendizagem significativa e desafiadora, tanto para o professor quanto para o aluno. Surpreendeu a insegurança de algumas professoras, o olhar desafiador e a ingenuidade de outras, mas todas tinham em comum o ensejo pela busca de respostas. Dessa forma, ressaltou-se a importância da leitura e das estratégias de compreensão leitora para que os processos de ensino e de aprendizagem do 
sistema de escrita alfabética e de leitura ocorram, simultaneamente, num contexto significativo para o aluno. Foi amplamente frisada a leitura como "ato de raciocínio" (COLOMER; CAMPS, 2002, p. 31), visto que o processo não se resume à mera decodificação de códigos escritos em códigos acústicos. Desse modo, o sentido da alfabetização se encontra no trabalho voltado à utilização da língua no contexto real do aluno, uma vez que este o descobrirá e fará seu uso numa perspectiva social.

Houve muita leitura, muito debate e muita socialização de ideias para que os grupos compreendessem os processos de alfabetização e letramento nas suas singularidades, mas, acima de tudo, na sua complementaridade.

\section{Professor: da leitura deleite ao ser leitor}

Ainda quanto às concepções sobre alfabetização e letramento, chegouse a outra reflexão: o que é aprender a ler? Uma cursista afirmou que "é decifrar o código escrito", ao passo que outra disse ser "preciso compreender o que se está lendo, se não, não é leitura”. O grupo repensou as afirmativas, analisando uma passagem presente na pauta do dia:

Ler significa ser questionado pelo mundo e por si mesmo, significa que certas respostas podem ser encontradas na escrita, significa poder ter acesso a essa escrita, significa construir uma resposta que integra parte das novas informações ao que já se é. [...] O ato de ler, em qualquer caso, é o meio de interrogar a escrita e não tolera a amputação de nenhum de seus aspectos (FOUCAMBERT, 1994, p. 5).

De acordo ainda com o autor, saber decifrar não pode ser confundido com saber ler, visto que da leitura se pretende obter informações, satisfação, questionamento, discussão, formulação de juízos, análise do caminho percorrido. A leitura precisa ter sentido ao leitor para que ele associe o que já sabe com o novo, e isso só se realizará quando o leitor atribuir um significado à escrita. Portanto, ler não é só "passar os olhos", é, sim, "interrogar" a escrita.

A relação leitura / leitor mereceu destaque nos momentos denominados de Leitura Deleite, efetuada inicialmente pela tutora e, no decorrer, por uma cursista, como estratégia de conhecimento, aprendizagem e motivação pelo prazer de ler. Como afirma Kleiman (2008, p. 50) o ensino de leitura consiste na "modelagem de estratégias" metacognitivas e cognitivas. Logo, cabe ao professor ensinar capacidades linguísticas específicas aos seus alunos, visto que dessa aprendizagem resultará a compreensão textual. Quando o leitor / ouvinte 
é guiado por objetivos, instigado a relembrar os conhecimentos prévios e provocado a levantar hipóteses sobre a leitura, automaticamente realizará operações mentais - inconscientes - que o ajudarão a compreender. Também o vocabulário pode ser entendido dentro do contexto da leitura, pela inferência; contudo isso só ocorrerá quando o professor mediar o processo, evidenciando aos seus alunos o caminho. Por meio de pistas, o professor pode conduzir o aluno à adivinhação lexical. Ao trabalhar com estratégias de leitura, o educador favorecerá uma educação que possibilita ao sujeito controlar sua aprendizagem, fazer escolhas, avaliar sua compreensão e criar suas próprias estratégias para compreender os diferentes textos. Logo, para o professor ensinar a leitura e a escrita, é condição básica considerar a "leitura de mundo" e a leitura da palavra como processos indissociáveis no seu fazer.

O estudo das teorias de leitura promoveu nos grupos o entendimento de que ler é muito mais do que decodificar letras e palavras e convertê-las em sons. Ler é, acima de tudo, atribuir significados às palavras, às orações e aos textos. A leitura é uma prática social e fundamental para entender o mundo. Para tanto, cabe ao educador encontrar diferentes estratégias para ensinar seus alunos a ler e a compreender os gêneros que compõem o cotidiano social e, mais do que isso, envolvê-los nessas práticas como seres atuantes que compreendem e agem no meio em que vivem. Nessa ótica, o professor estimula seus alunos a despertar os seus conhecimentos prévios para, assim, poder interpretar e extrair da leitura novos significados que lhes permitam construir novos saberes - a leitura numa interdependência dialética. Uma professora constatou que "tudo deve ser ensinado, tanto a leitura, quanto a compreensão, pois sozinho o aluno dificilmente aprenderá."

Nesse programa de estudos, a leitura foi o "o carro chefe". Houve muitos encontros dedicados à reflexão e estudo sobre a compreensão leitora que deve ocorrer antes, durante e após a leitura. As teorias de leitura de Solé (1998) e Kleiman (2008) foram o suporte dessa primeira etapa. Resgatar o gênero literário e outros gêneros textuais e oferecer espaço em aula para os alunos sentirem-se incentivados e envolvidos foi tarefa determinante de cada cursista que aspirou a melhores resultados no domínio oral e escrito de seus alunos. Os registros dessas atividades ${ }^{3}$ comprovam que a Leitura Deleite assumiu, para esse

\footnotetext{
${ }^{3}$ Relatórios enviados à Universidade Federal de Pernambuco, respectivos aos trabalhos realizados, referentes ao estudo dos fascículos 1 a 7 do Programa de Formação Continuada de Professores das Série Iniciais do Ensino Fundamental: Alfabetização e Linguagem.
} 
grupo de professoras, conteúdo diário nas salas de aula. O engajamento se tornou foco de outros professores da rede não participantes do Pró-Letramento, devido ao contágio da ideia. Além disso, circulava nos grupos a Sacola Deleite, ${ }^{4}$ recheada com sugestóes de leitura das próprias professoras cursistas.

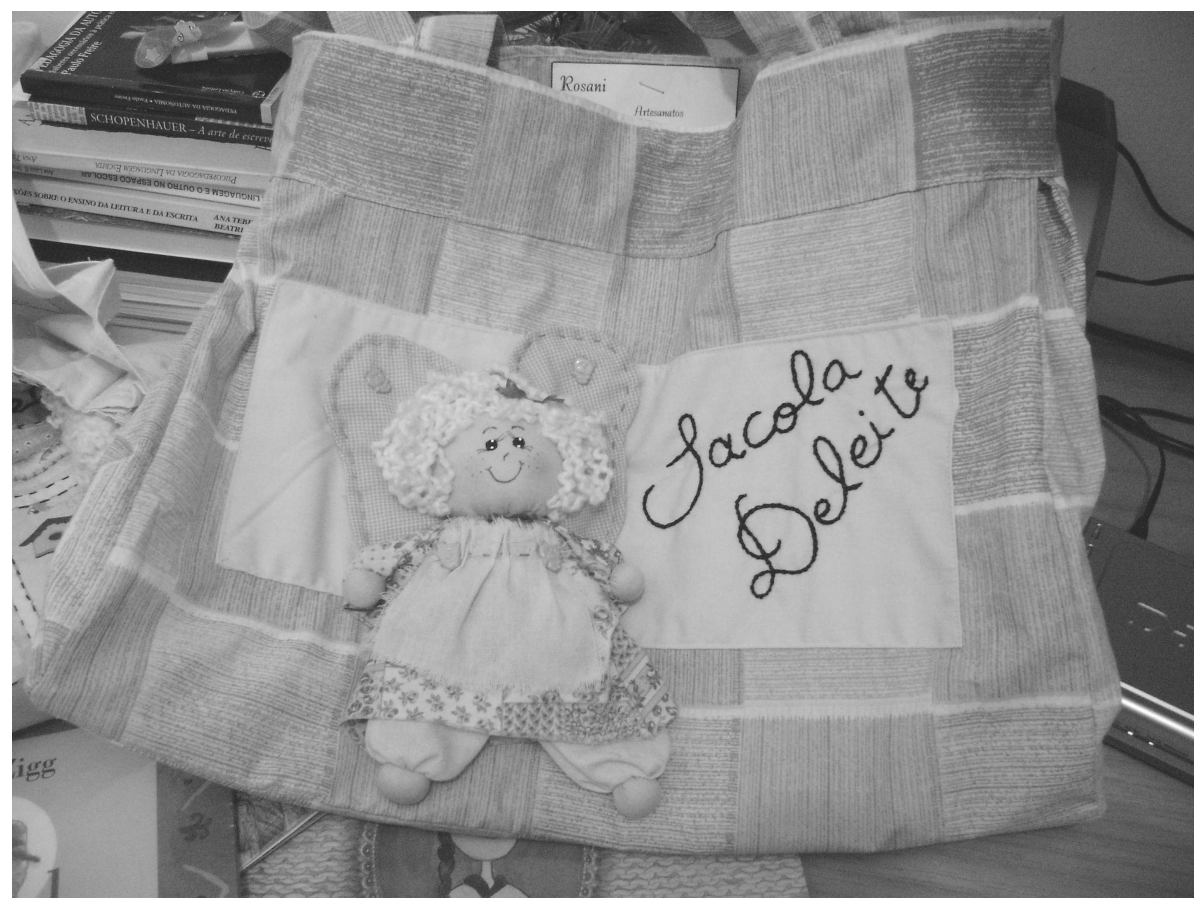

FIGURA 1 - Sacola deleite presente em todos os encontros

Conforme relatos, depois disso, nenhuma sala de aula inicia seu período sem os professores estarem de posse de um texto para leitura deleite e, como as próprias educadoras afirmaram, os alunos não admitem a falta.

Esses momentos foram oportunos também à reflexão sobre as leituras particulares do professor, uma vez que nem todos têm esse hábito. Sob o ponto de vista teórico, Solé (1998) afirma que o professor deve primeiramente mostrar sua paixão pela leitura, uma vez que ele é modelo para seus alunos. Logo, cabe a ele indagar-se de que tipo, ou seja, que modelo. Nessa perspectiva, o sujeito

\footnotetext{
${ }^{4}$ Bolsa a tiracolo, ilustrada artesanalmente com personagens infantis e enriquecida com literatura infantil, que circulava quinzenalmente nas escolas participantes do programa.
} 
apaixonado por aquilo que faz deixa transparecer essa paixão em seu olhar, em sua conduta, em sua fala. Foi constatado que o processo de leitura conquistou também a pessoa e o profissional, já que diariamente ele precisa estar munido de material previamente lido. É possível afirmar que os comportamentos não leitores se modificaram, uma vez que, nos encontros, os momentos deleite também foram direcionados ao ser adulto. Inúmeras vezes foi oferecida a "mercadoria" embalada em poemas, contos, crônicas, imagens e sugestões bibliográficas. Como exemplo sugestivo, a frase de Monteiro Lobato, "Livro é sobremesa, deve ser posto debaixo do nariz do freguês", enfoca a leitura como sabor e saber. Os bolinhos da Tia Nastácia (personagem de Monteiro Lobato no sítio do Pica Pau Amarelo) mesclaram-se ao momento e, por meio de estratégias, as próprias cursistas sugeriram-se leituras.

Com efeito, pode-se dizer que o envolvimento com o tema leitura foi do sujeito profissional e do sujeito educador, uma vez que ambos se deram na mesma pessoa. Para Hall (2001), o sujeito (aqui o professor) assume diferentes identidades em diferentes momentos. Consequentemente, à medida que os estudos, as trocas de experiências, os diálogos aprofundavam-se, as representações culturais e as (res)significaçóes se multiplicavam, e os cursistas adaptavam-se a elas. Hall (2001) afirma que as transformações identitárias se dão no nível de extensão e de intensidade: a primeira refere-se a relações sociais em âmbito global, e a segunda, a alterações íntimas e pessoais ocorridas no cotidiano. Logo, as mudanças identitárias ocorrem porque as identidades estão em constantes articulações e não são fechadas. Elas se modificam de acordo com as identificações do sujeito que nasce, tem uma história, sofre mudanças (mortes) e, ao longo da existência, vai formando ou construindo sua identidade. O grupo de professoras criou uma identificação no momento em que formulou perguntas relacionadas aos processos de ensino e de aprendizagem comum ao grupo. A construção de conhecimento na busca de respostas se deu numa intensidade e necessidade sincrônicas. As angústias foram ouvidas e entendidas, visto que eram comuns a todos os membros.

\section{Professor: um sujeito escritor}

A formação continuada questionou a escrita na perspectiva do letramento, uma vez que o aluno precisa compreender qual o objetivo da produção escrita proposta, a finalidade, a quem se destina seu texto e como ele deverá ser estruturado para atingir o objetivo. Constatou-se que não é suficiente o aluno conhecer um gênero textual, mas estar de posse de condições 
que o capacitem a fazer uso da escrita desse gênero. Foi percebido pela maioria que, antes de os professores participarem do programa pró-letramento, os textos escritos eram trabalhados com superficialidade, muitas vezes desprovidos de significação e, consequentemente, não oportunizavam ao aluno o desenvolvimento de habilidades cognitivas de abstração, como, o que escrevo, para quem, o que vou dizer, como vou dizer.

Acredita-se na necessidade da escrita para o domínio da língua. Ao refletir que a construção de conhecimento se fortalece / sedimenta com a escrita, foi instigante pensar sobre esta prática no meio docente, e a constatação a que se chegou foi a de que ela se restringe aos planejamentos de aula, registros nos diários de classe e a bilhetes ou recados deixados informalmente numa mesa de casa ou de trabalho. Considerar essa atividade significativa também para o sujeito / professor fortaleceu o estudo sobre letramento, pois fomentou uma busca pessoal / profissional por leituras. Inicialmente, houve certa relutância por parte de algumas cursistas em falar e escrever sobre si ou sobre os temas estudados. Contudo, as diferentes estratégias oferecidas nos encontros facultaram a percepção do professor da importância de ele analisar sua prática pedagógica, sua vida pessoal, e escrever essas reflexões, pois elas conduzem a um crescimento e a uma ressignificação de sua identidade pessoal e profissional.

Em cada encontro realizado, uma cursista registrava, no caderno da tutora (FIG. 2), os momentos significativos, como as aprendizagens construídas, as reflexões, as trocas de experiências. De formas singulares, os registros foram tecendo trajetórias ímpares por meio do uso de poemas, imagens, relatos, músicas, brincadeiras, afetividades. Desse modo, todas podiam ter acesso às representações anteriores e produzir as suas. Esses espaços contribuíram para a construção identitária dos grupos de estudo, pois cada uma foi se autopercebendo como ser humano e como parte integrante do grupo, e assumiu o papel identitário de professor, aluno, leitor, orador, ouvinte. Com efeito, pode-se afirmar que cada cursista fez uso de diferentes ferramentas metacognitivas para a elaboração e a conquista das diferentes identidades no campo vivido. 


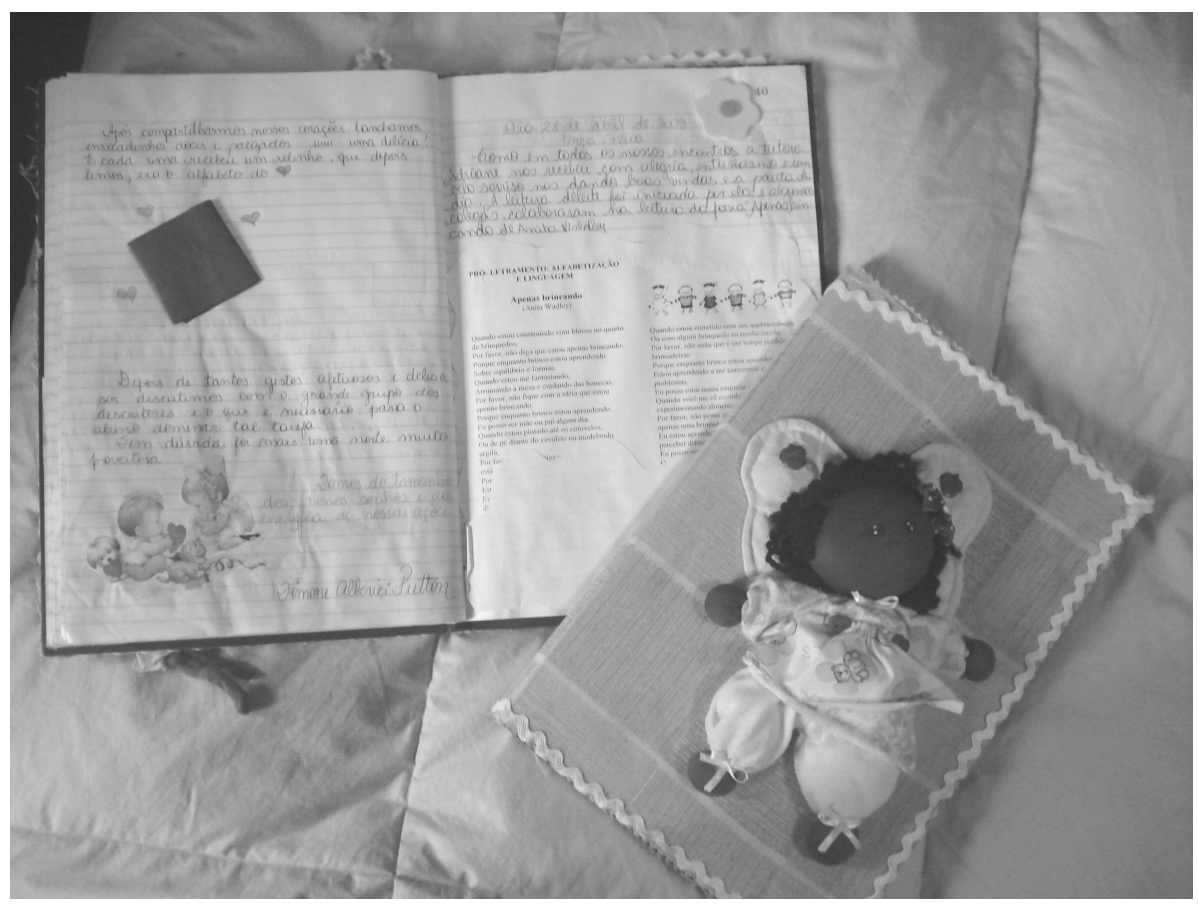

FIGURA 2 - Caderno de registros

Além disso, outra atividade enriqueceu a capacitação e o letramento do professor. Introduziu-se nos grupos o lanche "letrado" 5 ao sabor de "sonhos" recheados de poemas. Mesclando sabor e saber, essa atividade recebeu a denominação de "lanche letrado". Em todos os encontros, uma cursista era responsável por esse momento. Além de ele ser propício, devido ao horário e ao cansaço, servia como momento de reflexão do grupo, de entrosamento e de letramento. De modo geral, todas as situações foram ricas e saborosas. Variedades de alimentos, mensagens, histórias, músicas, resenhas, textos informativos, piadas, contos, orações e brincadeiras fortaleceram e estimularam o processo.

\footnotetext{
${ }_{5}^{5}$ Termo criado pela tutora para designar o descanso e o compartilhamento de um alimento, sempre planejado com enfoque no letramento.
} 


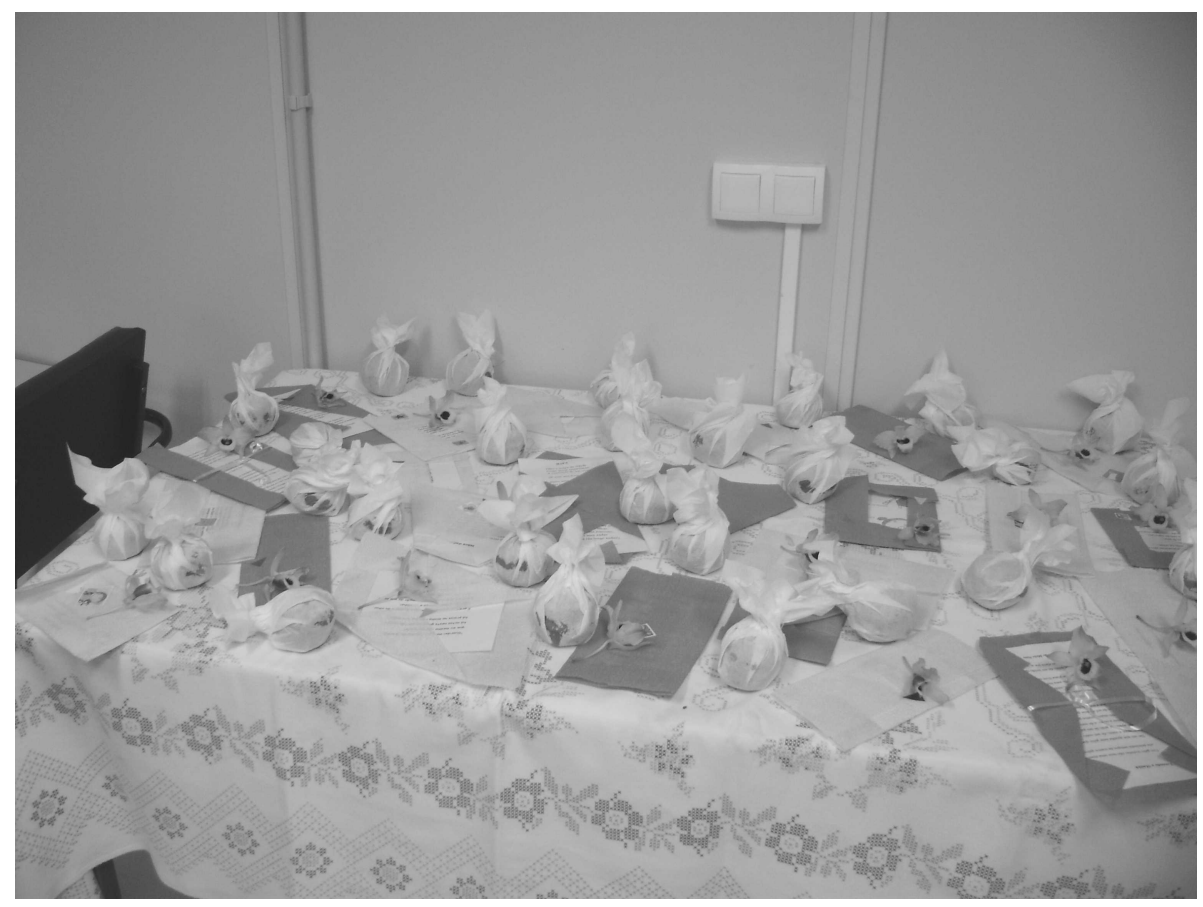

FIGURA 3 - Foto ilustrativa de um dos lanches letrados realizados no grupo

\section{Professor: novo sujeito, nova prática pedagógica}

Durante o processo de capacitação, percebeu-se o (re)planejamento por parte dos professores, visto que o estudo levava a uma modificação da prática. No início, o simples planejamento de uma atividade tornou-se tarefa árdua, na medida em que Eixos / Habilidades / Capacidades e Valores começaram a ser questionados, e o planejamento antes aplicado já não atendia às expectativas do professor. Essa inquietação proporcionou novas buscas e engajamento pedagógico. Foi de compreensão geral que a escola só capacitará seus educandos a serem seres autônomos e leitores capazes, se ensiná-los a construir suas próprias estratégias de leitura, compreensão e produção da escrita.

De acordo com o estudo do primeiro fascículo do programa Próletramento, Capacidades Linguisticas: Alfabetização e Letramento, os grupos constataram que é necessário repensar as Propostas Pedagógicas das escolas e os Planos de Estudo, visto que eles contemplam competências, mas não as particularizam e não definem a metodologia e as técnicas para o professor desenvolver com conhecimento e segurança o seu trabalho. 
O estudo do fascículo 2, Alfabetização e Letramento: Questôes Sobre Avaliação, contribuiu para uma reflexão profícua sobre avaliação por habilidades, sobre o currículo escolar, suas prioridades e as atividades que o professor pode proporcionar aos seus educandos, para que desenvolvam capacidades ainda não atingidas.

O terceiro fascículo, Tempo De Escrita e o Tempo De Leitura Na Sala De $A u l a$, objetivou uma reflexão quanto ao tempo de escrita e ao tempo de leitura na sala de aula. Também oportunizou ao professor observar melhor seu planejamento de aula. O Quadro de Rotina, registro sucinto de um turno de aula, ampliou as estratégias de trabalho do educador, na medida em que, diariamente, é feita uma retomada da aula desenvolvida. Este processo oportuniza uma sistematização do trabalho em sala de aula e das aprendizagens dimensionadas pelo professor. É um momento bastante significativo, já que permite uma nova intervenção do profissional da educação no que considera prioridade desenvolver em suas aulas.

A reflexão vivenciada no fascículo 4, Organização e Uso da Biblioteca Escolar e das Salas de Leitura, enfatizou a importância de o professor ser mediador no processo de leitura para a formação de um leitor. $\mathrm{Na}$ falta de biblioteca, cabe ao docente promover a leitura em sua sala de aula, como pode também levar livros de casa, criar cantinho da leitura em sala, realizar campanha de livros, criar biblioteca itinerante, visitar biblioteca municipal, confeccionar livrinhos com os alunos. O resgate de memórias de leitura contribuiu com os grupos no sentido de que eles mesmos analisaram o que foi positivo / negativo nas suas constituições como sujeitos leitores / não leitores. Por último, houve a constatação de que a biblioteca representa o centro cultural da escola e deve ser estruturada, organizada e mantida com acervo de qualidade e com profissionais competentes.

O quinto fascículo, O Lúdico Na Sala De Aula: Projetos e Jogos, reforçou o trabalho já desenvolvido na rede municipal, que acredita no brincar como integração da criança ao meio escolar e, ao mesmo tempo, como prática educativa, instrumentalizando o ensino de conteúdos desenvolvidos nos respectivos anos. O programa intensificou a responsabilidade do professor ao planejar o tipo de atividade lúdica que irá aplicar em sua turma, a fim de que ela tenha objetivos determinados. O lúdico aqui é entendido como o brincar com objetivo didático, portanto ele não pode se realizar simplesmente como um recurso desprovido de objetivos claros e de planejamento. Isso é um momento interativo entre professor e demais alunos e visa à aprendizagem 
como resultado do prazer. As professoras cursistas, em sua maioria atuantes nas classes de alfabetização, demonstraram ter bastante clareza sobre a importância do lúdico em seus planejamentos para que ocorra, por exemplo, a apropriação do Sistema de Escrita.

Outro tema bastante discutido foi o abordado pelo fascículo 6, $O$ Livro Didático Em Sala De Aula: Algumas Reflexôes, que, por conseguinte, deu-se na mesma época em que os catálogos e livros chegaram às escolas. Foi consciência geral a importância de escolher o livro didático, observando os cinco eixos norteadores do programa Pró-letramento: compreensão e valorização da cultura escrita, apropriação do sistema de escrita, leitura, produção de textos escritos e desenvolvimento da oralidade. Além disso, percebeu-se uma grande valorização desse material didático, antes desacreditado pela maioria.

O fascículo 7, Modos De Falar, Modos De Escrever, contribuiu para os grupos refletirem sobre as variedades e singularidades da fala nas diferentes regiōes brasileiras, explicou o conceito de competência comunicativa, enfocando a existência de uma integração entre os modos de falar e os modos de escrever. Foi frisado que a criança já está de posse de uma competência linguística quando chega à escola, contudo cabe ao profissional valorizá-la e, a partir disso, introduzi-la no mundo da escrita por meio do estudo dos gêneros. De um modo geral, o fascículo permitiu aos grupos a compreensão do ensinar a ler e a escrever num contexto de diferentes formas de escrita e de fala. Levar o aluno a aperfeiçoar sua linguagem e escrita requer sensibilidade do professor e conhecimento linguístico de que as diferenças entre os modos de falar / escrever são ocasionadas pelas variações culturais dos grupos sociais.

Além disso, foi bastante expressiva a palestra proferida pelo professor Dr. João Claudio Arendt, ${ }^{6}$ intitulada "Os sete equivocos no trabalho com literatura". Por assim dizer, Arendt considerou de vital importância o professor trabalhar em sala de aula com a literatura clássica. Apregoou ser essa uma porta de entrada exequível para a formação de novos leitores, se o professor disponibilizar-se a assumir perante seus alunos crianças / jovens uma postura pessoal e pedagógica voltada para o prazer de ler, de conhecer e de emocionarse. A palestra, como atividade do grupo de estudos do Pró-Letramento, foi um

${ }^{6} \mathrm{O}$ palestrante atua como docente do curso de Letras e do Programa de Mestrado em Letras, Cultura e Regionalidade da Universidade de Caxias do Sul. Também desenvolve pesquisa nas áreas de literatura brasileira e literatura sul-rio-grandense, abordando questôes referentes ao imaginário social, à cultura regional e à estética da recepção. 
momento de discussão, mas mais do que isso, foi uma oportunidade para conhecimento e reflexão visando ampliar / aperfeiçoar o olhar pedagógico no trabalho com a literatura, e desmitificou certos comportamentos muito comuns no meio educacional, como o "fazer pedagógico da ocasião", ou seja, que a maioria dos professores elabora seus planejamentos por meio de um texto "qualquer" que um colega descobriu, recebeu ou retirou de livro... Questôes são postas em prática, leituras feitas, textos escritos e reescritos, mas se indagarmos qual metodologia foi utilizada ou o porquê desse autor e obra, quantos saberão responder? A proposta do palestrante desestabilizou muitas crenças, costumes e dizeres do senso comum praticados diariamente nas séries iniciais e finais do Ensino Fundamental.

Outra passagem significativa no programa foi a do professor Clóvis Da Rolt, ${ }^{7}$ que encaminhou reflexões e discussões sobre o trabalho com linguagens em sala de aula, normalmente restrito somente ao texto escrito. O objetivo da oficina foi possibilitar aos participantes uma análise geral referente às relaçôes, às implicações e às dinâmicas no uso do código escrito da língua como elemento expressivo nas artes visuais. Pela observação de imagens de criações artísticas compiladas a partir da antiguidade até a contemporaneidade, os grupos puderam perceber como a arte é uma reflexão da ação humana e de suas necessidades e, portanto, em qualquer época em que for vista e analisada, age sobre seu leitor e congrega novas interpretações. Logo, ao trabalhar com arte, o professor possibilitará aos seus educandos aprofundamento, conhecimento e compreensão dos outros e de si mesmo. Concluiu-se que o espaço da sala de aula deve ser um espaço de formação de leitores e, assim, de diferentes e muitas leituras, não somente de textos escritos. É com leituras variadas da escrita do mundo que o sujeito evolui e manifesta suas mudanças no meio em que vive, modificando-o também; esse é o processo cultural.

\section{Considerações finais}

Começar um grupo de estudos, seja ele de alunos, seja de professores cursistas, exige empenho no sentido de conquistar um público para a participação. É necessário partir do pressuposto de que "a ideia precisa ser

${ }^{7}$ Clovis Da Rolt é Graduado em Educação Artística (UCS), com Especialização em Ética e Filosofia Política (UCS), Mestrado em Ciências Sociais (UNISINOS) e, atualmente, doutorando no Programa de Pós-Graduação em Ciências Sociais da UNISINOS. 
vendida” positiva e valorativamente. Com esse espírito, as professoras do município de Bento Gonçalves - $\mathrm{RS}$ - foram provocadas pela primeira vez a fazer parte dessa construção de conhecimentos. Acreditar no ser humano, acima de tudo, para acreditar no profissional, é essencial para envolver o educador e fomentar o espírito de grupo. Valorizar as participantes no seu saber, enfocar a importância de estarem presentes e de que somente pelo estudo obterão as respostas para os problemas de sala de aula são quesitos para a formação de um grupo de estudos. O participante precisa compreender que prestígio profissional vai muito além de estar de posse de um diploma, que prestígio profissional é saber lidar com situações complicadas no constante convívio com a comunidade escolar e, para que isso realmente ocorra, é necessário o aperfeiçoamento contínuo.

Entende-se que o programa Pró-Letramento interpelou as docentes a refletir sobre a importância da aprendizagem significativa no desenvolvimento do processo ensino-aprendizagem. Os grupos perceberam que seus alunos precisam sentir o prazer de querer aprender, principalmente nas séries iniciais em que a escola é, para muitos, um local bastante diferente das experiências já vivenciadas. Logo, o estímulo prazeroso à leitura de diferentes gêneros textuais promove o acesso dos alunos a muitos eventos de letramento. A constatação mais sublime é a de que o trabalho diário com leitura e escrita objetiva a familiaridade e a compreensão do professor e do aluno com diferentes assuntos e gêneros. Para tanto, é necessária a presença do professor mediador do processo, interagindo com seu aluno, comentando o texto, questionando, mobilizando o conhecimento de mundo para que o aluno faça suas previsões sobre o que vai ser lido.

No início do programa Pró-letramento foram revelados alguns questionamentos a respeito de dificuldades enfrentadas pelas professoras em suas turmas e a angústia pela busca de respostas e soluções. No último encontro do programa, os dois grupos reuniram-se e socializaram as perguntas elaboradas no primeiro encontro. As respostas estavam na fala de todas e foram construídas pelo estudo, pela perseverança e pelas trocas. É gratificante a comprovação do crescimento profissional e pessoal das cursistas. Hoje, estão mais críticas quanto ao processo ensino-aprendizagem e donas de maior embasamento teórico.

Ser indagada por uma professora sobre a interatividade e a temporalidade do programa Pró-letramento desafiou a reflexão de que ele vai ao encontro da inovação, visto que trabalha diretamente com professor / aluno. O professor participante jamais retornará ao trabalho aplicando uma metodologia 
descontextualizada e desprovida da prática do letramento. Com certeza, a formação continuada é uma oportunidade ímpar para os envolvidos questionarem-se e atribuírem, voluntariamente, novos significados à prática pedagógica e a si mesmos. Comprova-se esta constatação pelos comentários citados a seguir, proferidos por ex-cursistas em encontro realizado alguns meses após o término do programa aqui referido:

Na escola a gente sente a diferença de quem faz e quem não faz o próletramento. Pra quem faz, a leitura deleite é bem valorizada, para os outros, éperda de tempo.

A oralidade é trabalhada, o que ajuda no processo de leitura e escrita dos alunos. A produção de texto émais coerente, com boas ideias, porque a leitura forma alunos leitores e escritores.

A gente se torna mais investigativo e exigente, sabendo selecionar melhor as leituras para levar para a sala.

Ao planejar minha aula, questiono-me sobre o que meu aluno aprenderá com isso.

Os alunos gostam muito da sacola deleite.

Dei-me conta de que é possivel explorar os diversos gêneros literários e não literários.

Diante do que aplicamos, os alunos tornam-se mais investigadores, questionadores, envolvem-se mais com a leitura, tornando esse momento mais prazeroso e produtivo.

O letramento abriu caminhos para uma constante busca do saber e a coragem da mudança.

Com o programa, as aulas ficaram mais completas, com uma sequência de conteúdos.

Aprendi a tomar a leitura deleite como ponto de partida para promover o encontro das crianças com o texto.

Cresci como professora e vejo a linguagem de forma diferente, mais agradável e significativa.

Com o pró-letramento, minha forma de dar aula se abriu. Acho que fiquei mais encantada que os próprios alunos. 
Porém, ainda é necessário trilhar novas estratégias, visto que muitas são as escolas em que subjazem modelos de letramento parciais. Seria uma estratégia propícia o sistema governamental oferecer material de estudo aos professores, além do material organizado pelo Programa Pró-Letramento, a fim de que o professor compreenda o desafio de sistematizar os conceitos e formalizar os conteúdos. As justificativas do fracasso escolar continuarão perpetuando-se como resultado de um meio social desfavorecido, em que pais não oferecem eventos de letramento aos seus filhos. Logo, a escola também não sabe que esse quadro poderia ser modificado, se ela, como agente de letramento, trabalhasse a aquisição da escrita, considerando os aspectos sociais e contextuais de seus alunos. Portanto, as deficiências de ensino precisam ser resolvidas, capacitando os seus representantes da cultura letrada, aprimorando os currículos e oferecendo materiais didáticos possibilitadores de questionamentos, problematizadores que desenvolvam múltiplas habilidades.

Concluo que o Programa Pró-letramento está voltado para essa concepção de leitura como conteúdo a ser ensinado. Isso exige planejamento do professor, incentivo à leitura na escola, material de leitura e profissionais habilitados nas bibliotecas, oportunidade de capacitação aos professores e estrutura adequada para atender às necessidades das escolas. Além disso, fica comprovado que qualquer processo de ensino-aprendizagem, para se realizar satisfatoriamente, necessita de um comprometimento do profissional de educação voltado para a formação continuada que vise provocar situações de reflexão sobre a prática pedagógica e de estudos que viabilizarão novas ações.

Para finalizar estas considerações, pode-se parafrasear Bakhtin (1997), quando afirma que tudo o que o ser humano constrói é o "eco" de outras construçôes. Com base nessa afirmativa, acredita-se ser possível refletir sobre a educação: "Qual eco, eu, profissional da educação, ressoo nos meus alunos?"

\section{Referências Bibliográficas}

COLOMER, Teresa; CAMPS, Ana. Ensinar a ler, ensinar a compreender. Porto Alegre: ArtMed, 2002.

BAKHTIN, Mikhail Mikhailovitch. Estética da criação verbal. São Paulo: Martins Fontes, 1997.

FOUCAMBERT, Jean. A leitura em questão. Porto Alegre: ArtMed, 1994.

HALL, Stuart. A Identidade cultural na pós-modernidade. Rio de Janeiro: DP\&A, 2001. 
KLEIMAN, Ângela. Oficina de leitura: teoria e prática. Campinas: Pontes, 2008. KLEIMAN, Ângela. Os significados do letramento. Uma nova perspectiva sobre a prática social da escrita. Campinas: Mercado das Letras, 1995.

KLEIMAN, Ângela. Texto e leitor: aspectos cognitivos da leitura. Campinas: Pontes, 1999.

MINISTÉRIO DA EDUCAÇÃO. Pró-Letramento: Programa de Formação Continuada de Professores dos Anos / Séries Iniciais do Ensino Fundamental: Alfabetização e Linguagem. Incluindo SAEB/Prova Brasil matriz de referência/ Secretaria de Educação Básica. Brasília: Secretaria de Educação Básica, 2008.

NERY, Alfredina. Modalidades organizativas do trabalho pedagógico: uma possibilidade. Ensino fundamental de nove anos: orientaçôes para a inclusão da criança de seis anos de idade. Brasília: Ministério da Educação, Secretaria de Educação Básica, 2007.

PAVIANI, Jayme. Cultura, humanismo e globalização. Caxias do Sul: Educs, 2004. SOARES, Magda. Alfabetização e letramento. São Paulo: Contexto, 2008.

SOARES, Magda. Alfabetização e letramento: Caminhos e Descaminhos. Revista Pátio. Ano VIII, n. 29, fev./abr. 2004.

SOARES, Magda. Letramento e Alfabetização: as muitas facetas. Trabalho apresentado no GT Alfabetização, Leitura e Escrita, durante a 26a REUNIÃO ANUAL DA ANPEd, realizada em Poços de Caldas, MG, de 5 a 8 de outubro de 2003.

SOARES, Magda. Letramento: um tema em três gêneros. Belo Horizonte: Autêntica, 1998.

SOLÉ, Isabel. Estratégias de leitura. Porto Alegre: ArtMed, 1998.

Recebido em 4/10/2010. Aprovado em 2/11/2011. 